\title{
Antioxidant activity of extracts from Euryale ferox seed
}

\author{
Si Eun Lee ${ }^{1}$, Eun Mi Ju${ }^{1}$, Jeong Hee Kim ${ }^{1,2}$ \\ ${ }^{1}$ Department of Oral Biochemistry, College of Dentistry, Kyung Hee \\ University, Seoul, 130-701, Korea \\ ${ }^{2}$ Corresponding author: Tel, +82-2-961-0915; \\ Fax, +82-2-960-1457, E-mail, jhkimh@khu.ac.kr
}

Accepted 3 April 2002

Abbreviations: DPPH, 1, 1-diphenyl-2-picrylhydrazyl; SOD, superoxide dismutase; CAT, catalase; GPX, glutathione peroxidase

\begin{abstract}
Euryale ferox has been widely used in traditional oriental medicine to treat a variety of illness. However, very little is known about the cellular actions by which this plant mediates its therapeutic effects. Various aspects of antioxidant activity were evaluated in total extracts and fractions derived from Euryale ferox. Total extracts $\left(\mathrm{IC}_{50} 5.6 \mu \mathrm{g} / \mathrm{ml}\right)$ showed relatively high level radical scavenging activity toward 1, 1-diphenyl-2-picrylhydrazyl (DPPH) and also enhanced viability of Chinese hamster lung fibroblast (V79-4) cells under exposure to oxidative agents. Upon further fractionation, the highest levels of DPPH radical scavenging and lipid peroxidation inhibitory activities were found in the ethyl acetate and butanol fractions. The ethyl acetate fractions, the butanol fractions, and total extracts of Euryale ferox also dose-dependently enhanced the activities of superoxide dismutase, catalase and glutathione peroxidase in V79-4 cells. Of these three antioxidant enzymes, glutathione peroxidase activity was most strongly induced. Taken together, our findings show that Euryale ferox contains a significant antioxidant activity and that specific components in the ethyl acetate and butanol fractions may play an important role in mediating these antioxidant properties.
\end{abstract}

Keywords: Antioxidant activity; Antioxidant enzymes; Euryale ferox; Lipid peroxidation; Radical scavenging

\section{Introduction}

Oxidative modification of DNA, proteins, lipids and small cellular molecules by reactive oxygen species (ROS) plays a role in a wide range of common diseases and age-related degenerative conditions (for review see Finkel and Holbrook, 2000). Disease states which are known to be affected by ROS include cardiovascular disease (Witztum, 1993), neurodegenerative diseases such as Alzheimer's disease (Frlich and Riederer, 1995), mutations and cancer (Borek, 1991).

To protect themselves against toxic free radicals and other ROS, cells have developed a variety of antioxidant defenses. These include enzymes such as superoxide dismutase (SOD), which dismutates superoxide; catalase (CAT), which converts hydrogen peroxide into water and oxygen, and glutathione peroxidase (GPX), which destroys toxic peroxides. Other molecules that can counteract ROS include glutathione, flavonoids, ubiquinol10, glucose, and albumin. External sources of antioxidative protection include vitamins $\mathrm{C}, \mathrm{E}, \mathrm{A}$, and provitamin $A$, as well as the minerals selenium and zinc (Halliwell and Gutteridge, 1998).

Phytochemicals from natural products are also important in that they provide further protection against oxidative damage from free radicals. Numerous natural antioxidants have been studied in fruits and vegetables (Cao et al., 1996; Wang et al., 1996; Brown and RiceEvans, 1998), oilseeds (Deiana et al., 1999), herbs (Kitts et al., 2000), tea (Roedig-Penman and Gordon, 1997), berry crops (Wang and Jiao, 2000), propolis (Banskota et al., 2000), Ginkgo biloba (Gohil et al., 2000) and Panax ginseng (Keum et al., 2000). The plant used in this study, Euryale ferox (Nymphaeaceae), was selected based on its traditional use in Chinese medicine. Euryale ferox has been considered to be a tonic and has also been recommended for the treatment of pyodermas, hernia and leukorrhea. Glycosylsterols and cerebrosides were identified in Euryale ferox by nuclear magnetic resonance and mass spectroscopic methods (Zhao et al., 1989, 1994). In general, very little research has been done on biological activity of this plant. Puri et al. (2000) investigated the effect of certain plant products on cell-mediated immunity (CMI) and humoral immunity when administered to mothers after childbirth. These investigators found that the total extracts of Euryale ferox stimulated humoral immunity to a greater extent than CMI.

In the present study, the antioxidative actions of Euryale ferox were evaluated by their abilities to scavenge 1, 1diphenyl-2-picrylhydrazyl (DPPH) free radicals, to protect cell viability and to inhibit the formation of lipid peroxides. The effect of Euryale ferox on the activity of antioxidant enzymes such as SOD, CAT and GPX was also investigated. 


\section{Materials and Methods}

\section{Preparation of plant extracts}

Euryale ferox $(100 \mathrm{~g})$ was extracted at $80^{\circ} \mathrm{C}$ in $70 \%$ methanol for $3 \mathrm{~h}$. The extract was then filtered and the filtrate was concentrated with a vacuum rotary evaporator (Eyela, Japan) under low pressure. The residue was freeze-dried (llsin, Korea) and stored at $-70^{\circ} \mathrm{C}$. The total extracts were extracted with $\mathrm{n}$-hexane, dichloromethane, ethyl acetate and n-butanol, in a stepwise manner, using separatory funnels. Fractions were collected and the solvents were removed by rotary evaporation. The powder was dissolved in dimethyl sulfoxide (DMSO) and diluted with phosphate buffered saline (PBS, pH 7.4) to give final concentrations of total extracts and fractions ranging from 0.8 to $100 \mu \mathrm{g} / \mathrm{ml}$.

\section{Cell culture}

Chinese hamster lung fibroblast, V79-4 (ATCC CCL-93) cells were maintained at $37^{\circ} \mathrm{C}$ in an incubator with a humidified atmosphere of $5 \% \mathrm{CO}_{2} / 95 \% \mathrm{O}_{2}$. Cells were cultured in Dulbecco's modified Eagle's medium (DMEM, Gibco BRL, USA) containing $5 \%$ fetal bovine serum (FBS, BioWhittaker, USA), $100 \mu \mathrm{g} / \mathrm{ml}$ of streptomycin, $100 \mathrm{unit} / \mathrm{ml}$ of penicillin (Gibco BRL) and 2 mM L-glutamine (Gibco BRL).

\section{DPPH radical scavenging activity}

In order to measure the antioxidant activity of Euryale ferox, the DPPH free radical scavenging assay was carried out according to the procedure described by Blosi et al. (1958). Total extracts and fractions of Euryale ferox at various concentrations $(0.8,4,20$, and $100 \mu \mathrm{g} /$ $\mathrm{ml}$ ) were added to a $1.5 \times 10^{-4} \mathrm{M}$ solution of DPPH (Sigma, St. Louis, MO, USA) in methanol and the reaction mixture was shaken vigorously. The amount of DPPH remaining was determined at $520 \mathrm{~nm}$, and the radical scavenging activity was obtained from the following equation:

Radical scavenging activity $(\%)=\left\{\left(\mathrm{OD}_{\text {control }}-\mathrm{OD}_{\text {sample }}\right) /\right.$ $\mathrm{OD}_{\text {control }} \times 100$

The antioxidant activity of Euryale ferox was expressed as $I C_{50}$. The $I C_{50}$ value was defined as the concentration (in $\mu \mathrm{g} / \mathrm{ml}$ ) of extracts that inhibits the formation of DPPH radicals by $50 \%$.

\section{Nuclear staining with propidium iodide}

Cells used in this study were constantly observed under an inverted phase-contrast microscope (Olympus). V794 cells were placed in a $60 \mathrm{~mm}$ culture plate at a concentration of $1.2 \times 10^{5} \mathrm{cells} / \mathrm{ml}$. Sixteen $\mathrm{hr}$ after plating, cells were treated with $100 \mu \mathrm{g} / \mathrm{ml}$ of Euryale ferox extracts and after $1 \mathrm{~h}$ of further incubation, $1 \mathrm{mM}$ $\mathrm{H}_{2} \mathrm{O}_{2}$ was added to the culture. After $24 \mathrm{~h}$, cells were harvested by centrifugation and washed with PBS twice.
Cells were then resuspended in PBS at a concentration of $4 \times 10^{5} \mathrm{cell} / \mathrm{s} / \mathrm{ml}$ and placed onto a microscope slide using a cytospin (Hanil, Korea), which was left at room temperature for dryness. Cells were fixed with cold ethanol in the dark. The fixed cells were washed with PBS and stained with $2.5 \mu \mathrm{g} / \mathrm{ml}$ of propidium iodide and DNase-free RNase $(100 \mu \mathrm{g} / \mathrm{ml})$. The morphology of the stained cells was examined under a fluorescence microscope (E800, Nikon, Japan).

\section{Cell viability}

Cell viability was estimated by the MTT assay, which is based on the cleavage of a tetrazolium salt by mitochondrial dehydrogenases in viable cells (Hansen et al., 1989). V79-4 cells were seeded in a 96 well plate at a concentration of $1.2 \times 10^{5} \mathrm{cells} / \mathrm{ml}$. Sixteen $\mathrm{h}$ after plating, cells were treated with various concentrations of total extracts, ethyl acetate fractions, or butanol fractions $(4,20$, and $100 \mu \mathrm{g} / \mathrm{ml})$ and $1 \mathrm{~h}$ later $1 \mathrm{mM} \mathrm{H}_{2} \mathrm{O}_{2}$ was added to the culture. Cells were incubated for an additional $24 \mathrm{~h}$ at $37^{\circ} \mathrm{C}$. During the last $4 \mathrm{~h}$, cells were incubated with $20 \mu \mathrm{l}$ of MTT stock solution $(5 \mathrm{mg} / \mathrm{ml})$ in $200 \mu \mathrm{l}$ medium at $37^{\circ} \mathrm{C}$. Samples were then extracted with acidic isopropanol and the absorbance was measured with an ELISA reader (Bio-Rad, USA) at 570 $\mathrm{nm}$. The relative cell viability was determined by the amount of MTT converted to the insoluble formazan salt. The data are expressed as mean percentage of viable cells as compared to the respective control cultures.

\section{Lipid peroxidation inhibitory activity}

Lipid peroxidation was assayed by the measurement of malonedialdehyde (MDA) according to the method of Ohkawa et al. (1979). The cells were exposed to total extracts, ethyl acetate fractions or butanol fractions of Euryale ferox at various concentrations $(4,20$ and 100

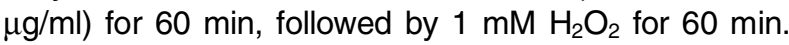
Cells were then washed with cold PBS, scraped and homogenized in ice-cold $1.15 \% \mathrm{KCl}$. Samples containing $100 \mu \mathrm{l}$ of cell lysates were combined with $0.2 \mathrm{ml}$ of $8.1 \%$ SDS, $1.5 \mathrm{ml}$ of $20 \%$ acetic acid adjusted to $\mathrm{pH}$ 3.5 and $1.5 \mathrm{ml}$ of $0.8 \%$ thiobarbituric acid. The mixture was brought to a final volume of $4.0 \mathrm{ml}$ with distilled water and heated to $95^{\circ} \mathrm{C}$ for $120 \mathrm{~min}$. After cooling to room temperature, $5.0 \mathrm{ml}$ of a mixture of $\mathrm{n}$-butanol and pyridine $(15: 1, \mathrm{v} / \mathrm{v})$ was added to each sample and the mixture was shaken vigorously. After centrifugation at $1500 \mathrm{rpm}$ for $10 \mathrm{~min}$, the supernatant fraction was isolated and the absorbance was measured at $532 \mathrm{~nm}$. Inhibitory activity towards lipid peroxidation was expressed as $\mathrm{IC}_{50}$.

\section{Assays for antioxidant enzymes}

The cells were treated with 4,20 and $100 \mu \mathrm{g} / \mathrm{ml}$ of total extracts, ethyl acetate fractions or butanol fractions of 
Euryale ferox for $60 \mathrm{~min}$. The cells were then lysed in a lysis buffer appropriate for the requirements of each assay, as described below. The method of Bradford (1976) was used to determine protein concentrations. Results are expressed as relative percentage of enzyme activity per $\mathrm{mg}$ protein compared with corresponding control cultures.

\section{Superoxide dismutase (SOD) activity}

SOD activity was assayed by the nitroblue tetrazolium (NBT) method of Beauchamp and Fridovich (1971). NBT is reduced to blue formazan by $\mathrm{O}_{2}^{-}$, which has a strong absorbance at $560 \mathrm{~nm}$. The presence of SOD inhibits this reaction. The cells were homogenized in $0.05 \mathrm{M}$ sodium carbonate buffer, $\mathrm{pH}$ 10.2. The assay mixture consisted of $0.05 \mathrm{M}$ sodium carbonate buffer, pH 10.2 containing $3 \mathrm{mM}$ xanthine, $0.75 \mathrm{mM} \mathrm{NBT}, 3 \mathrm{mM}$ EDTA, $1.5 \mathrm{mg} / \mathrm{ml} \mathrm{BSA}$ and $50 \mu \mathrm{l}$ of homogenate. The reaction was initiated by the addition of $50 \mu$ of xanthine oxidase $(0.1 \mathrm{mg} / \mathrm{ml})$ and incubated for $30 \mathrm{~min}$ at room temperature. The reaction was stopped by adding $6 \mathrm{mM}$ copper (II) chloride and centrifuged at $1500 \mathrm{rpm}$ for 10 min. The absorbance of blue formazan at $560 \mathrm{~nm}$ was then determined in the supernatants.

\section{Catalase (CAT) activity}

The reaction mixture contained $12 \mu \mathrm{l}$ of $3 \%(\mathrm{v} / \mathrm{v}) \mathrm{H}_{2} \mathrm{O}_{2}$ and $100 \mu \mathrm{l}$ of cell lysates in $50 \mathrm{mM}$ phosphate buffer $(\mathrm{pH} 7.0)$ at a final volume of $1.0 \mathrm{ml}$. Samples were incubated for $2 \mathrm{~min}$ at $37^{\circ} \mathrm{C}$ and the absorbance of the samples were monitored for $5 \mathrm{~min}$ at $240 \mathrm{~nm}$. The change in absorbance is proportional to the breakdown of $\mathrm{H}_{2} \mathrm{O}_{2}$ (Carrillo et al., 1991).

\section{Glutathione peroxidase (GPX) activity}

GPX was assayed by the method of Paglia and Valentine (1967). The reaction mixture contained $0.1 \mathrm{M}$ phosphate buffer, $\mathrm{pH}$ 7.0, $1 \mathrm{mM}$ EDTA, $10 \mathrm{mM}$ glutathione (GSH), $1 \mathrm{mM} \mathrm{NaN}_{3}, 1$ unit of glutathione reductase, $1.5 \mathrm{mM} \mathrm{NADPH}$ and $0.1 \mathrm{ml}$ of cell lysates. After incubation for $10 \mathrm{~min}$ at $37^{\circ} \mathrm{C}, \mathrm{H}_{2} \mathrm{O}_{2}$ was added to each sample at a final concentration of $1 \mathrm{mM}$. GPX activity was measured as the rate of NADPH oxidation at $340 \mathrm{~nm}$.

\section{Results}

\section{DPPH radical scavenging activity of total extracts and fractions of Euryale ferox}

The antioxidant activities of Euryale ferox extracts were evaluated by DPPH free radical scavenging activity, by the protective effect on cell viability, and by inhibition of lipid peroxidation. The DPPH radical scavenging activities of total extracts and fractions are shown in

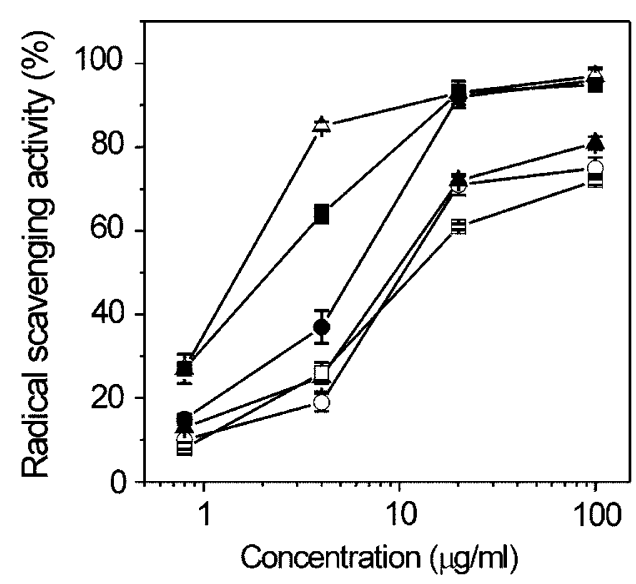

Figure 1. DPPH radical scavenging activity of total extracts and fractions of Euryale ferox. Each experiment was performed at least 3 times and data are expressed as average percent change from control \pm S.D. -Total extracts, $\bigcirc$-Hexane fractions, $\Delta$-Dichloromethane fractions, $\triangle$-Ethyl acetate fractions, -Butanol fractions and -Water fractions.

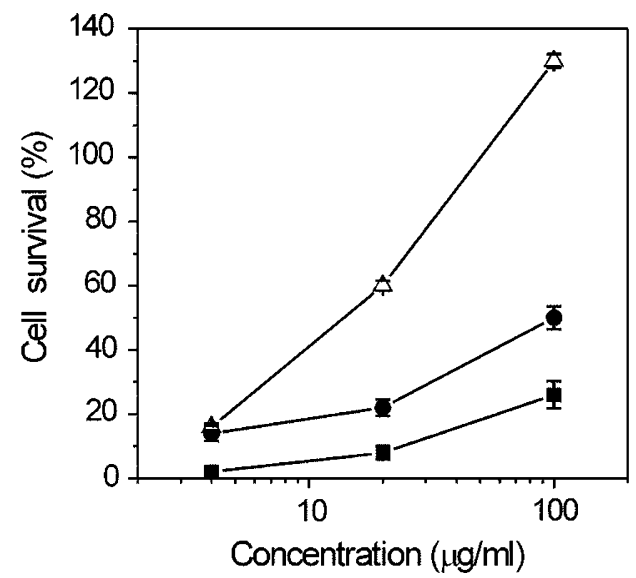

Figure 2. Protective effect of total extracts, ethyl acetate and butanol fractions of Euryale ferox against $\mathrm{H}_{2} \mathrm{O}_{2}$-induced oxidative damage in V79-4 cells. Each experiment was performed at least 3 times and data are expressed as average percent change from control \pm S.D. - -Total extracts, $\triangle$-Ethyl acetate fractions and $\boldsymbol{\square}$-Butanol fractions.

Figure 1. Total extracts of Euryale ferox showed relatively high DPPH radical scavenging activity, with an average $I_{50}$ value of $5.6 \mu \mathrm{g} / \mathrm{ml}$. Relative to other fractionated samples, the ethyl acetate and butanol fractions had the highest DPPH radical scavenging activity, with $\mathrm{IC}_{50}$ values of 1.5 and $2.2 \mu \mathrm{g} / \mathrm{ml}$, respectively.

\section{Protective effect of Euryale ferox extracts on cell survival}

We measured the protective effect of total extracts, ethyl acetate fractions and butanol fractions on cell survival in $\mathrm{H}_{2} \mathrm{O}_{2}$ treated cells. Cells were treated with extract samples for $1 \mathrm{~h}$ prior to the addition of $\mathrm{H}_{2} \mathrm{O}_{2}$. Control cells were treated with $\mathrm{H}_{2} \mathrm{O}_{2}$ in the presence of vehicle 
A

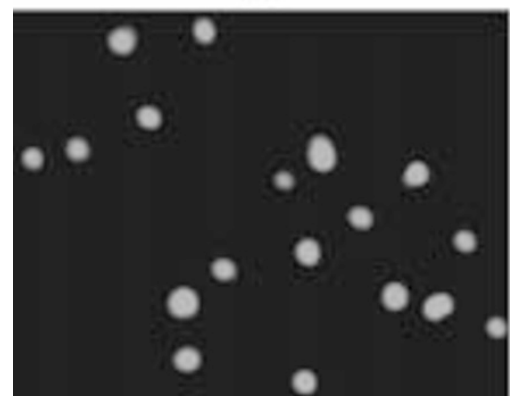

B

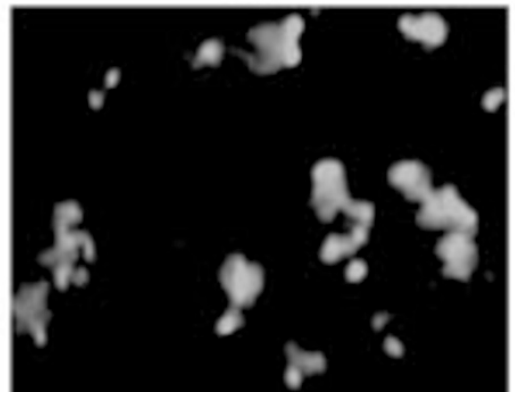

C

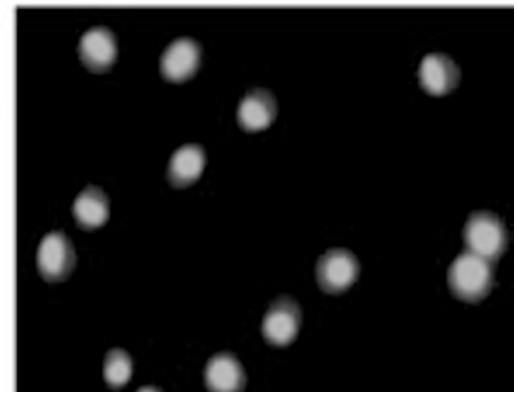

Figure 3. Protective effect of total extracts of Euryale ferox against $\mathrm{H}_{2} \mathrm{O}_{2}$-induced apoptosis in V79-4 cells. Cellular morphological changes were observed using

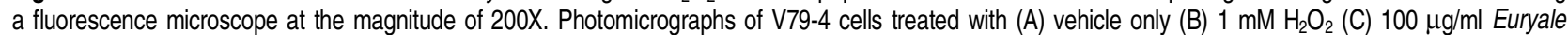
ferox extracts for $1 \mathrm{~h}$ prior to the addition of $\mathrm{H}_{2} \mathrm{O}_{2}$.

only. The final concentration of DMSO was below $0.1 \%$ in this study. There was no cyto-protective effect of DMSO at this concentration. The relative cell survival was determined $24 \mathrm{~h}$ later by the MTT assay. As shown in Figure 2, treatment with Euryale ferox extracts induced a dose-dependent increase in cell survival. Interestingly, treatment with the ethyl acetate fractions dramatically increased the cell survival of $\mathrm{H}_{2} \mathrm{O}_{2}$-treated cells. At a dose of $100 \mu \mathrm{g} / \mathrm{ml}$, the ethyl acetate fractions actually stimulated cell survival to a level higher than that observed in control cells.

\section{Reduction of $\mathrm{H}_{2} \mathrm{O}_{2}$-induced nuclear fragmentation by Euryale ferox extract treatment}

In order to analyze the protective effect of Euryale ferox extracts on $\mathrm{H}_{2} \mathrm{O}_{2}$-induced apoptosis, we fluorescently stained nuclei of V79-4 cells treated with $\mathrm{H}_{2} \mathrm{O}_{2}$ alone or with both Euryale ferox extracts and $\mathrm{H}_{2} \mathrm{O}_{2}$. As shown in Figure 3 , control cells revealed intact nuclei, but cells treated with $1 \mathrm{mM}$ of $\mathrm{H}_{2} \mathrm{O}_{2}$ showed significant nuclear fragmentation. However, when we treated cells with Euryale ferox extracts $1 \mathrm{~h}$ prior to $\mathrm{H}_{2} \mathrm{O}_{2}$ treatment, dramatic reduction in nuclear fragmentation was observed.

\section{Effect of Euryale ferox extracts on lipid peroxidation}

We also tested the ability of total extracts, ethyl acetate fractions, and butanol fractions to inhibit lipid peroxidation in $\mathrm{H}_{2} \mathrm{O}_{2}$-treated V79-4 cells. Pretreating cells with total extracts modestly reduced lipid peroxidation with an $\mathrm{IC}_{50}$ value of $20.5 \mu \mathrm{g} / \mathrm{ml}$ (Figure 4). The ethyl acetate and butanol fractions were found to have high levels of inhibitory activity, with $\mathrm{IC}_{50}$ values of 5.1 and $6.3 \mu \mathrm{g} / \mathrm{ml}$, respectively.

\section{Effect of total extracts and fractions of Euryale ferox on SOD, CAT and GPX}

In order to investigate whether these antioxidant properties of Euryale ferox extracts are mediated by an increase in antioxidant enzymes, we measured SOD,

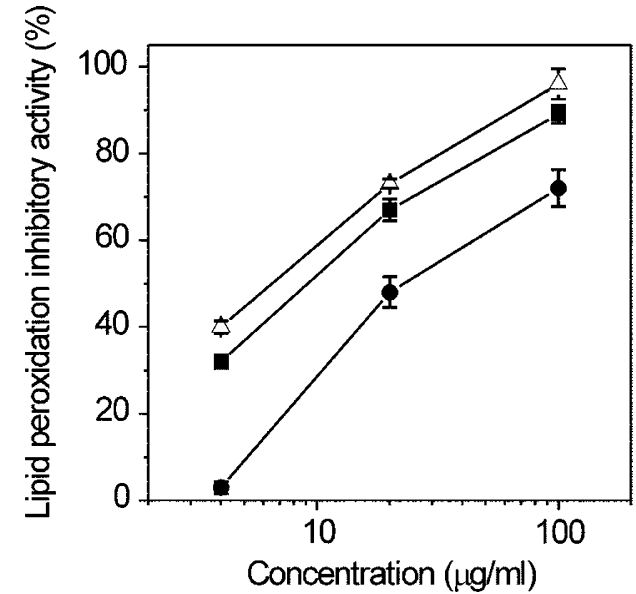

Figure 4. Lipid peroxidation inhibitory activity of total extracts, ethyl acetate and butanol fractions of Euryale ferox against $\mathrm{H}_{2} \mathrm{O}_{2}$-induced oxidative damage in V79-4 cells. Each experiment was performed at least 3 times and data are expressed as average percent change from control \pm S.D. -Total extracts, $\triangle$-Ethyl acetate fractions and $\mathbf{- B u t a n o l}$ fractions.

CAT and GPX activities in V79-4 cells treated with total extracts or fractionated samples (Figure 5). Treatment with total extracts at doses of 4,20 and $100 \mu \mathrm{g} / \mathrm{ml}$ increased SOD activity by 9,20 and $24 \%$, respectively (Figure 5A). Cells treated with ethyl acetate fractions of Euryale ferox exhibited even higher levels of SOD activity $(34 \%$ increase at $100 \mu \mathrm{g} / \mathrm{ml})$. Cells treated with $100 \mu \mathrm{g} / \mathrm{ml}$ of the butanol fractions exhibited a $26 \%$ increase in SOD activity. All samples tested dosedependently increased SOD activity. Of the samples tested, the ethyl acetate fraction most strongly activated SOD within the concentration range used. The activity of SOD in control cell untreated with extracts was $24.9 \pm 1.5 \mathrm{U} / \mathrm{mg}$ protein. CAT activity was concomitantly increased when cells were treated with $100 \mu \mathrm{g} / \mathrm{ml}$ of total extracts (23\% increase), the ethyl acetate fractions (32\% increase), and the butanol fractions $(26 \%$ increase) (Figure 5B). Each of the samples dosedependently increased CAT activity over a range of 4 to $100 \mu \mathrm{g} / \mathrm{ml}$. The ethyl acetate fractions most strongly 
A

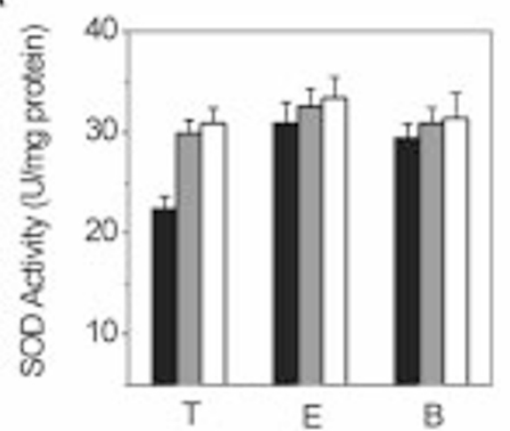

B

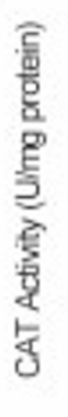

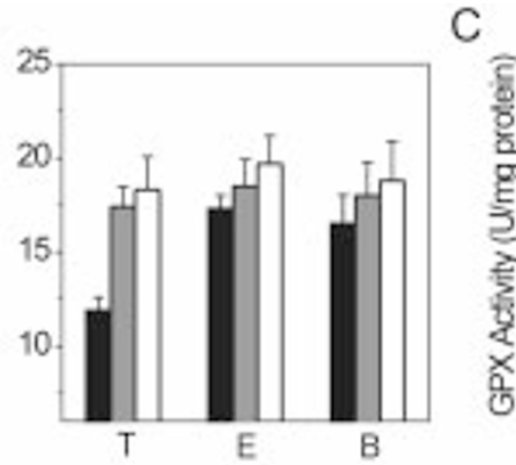

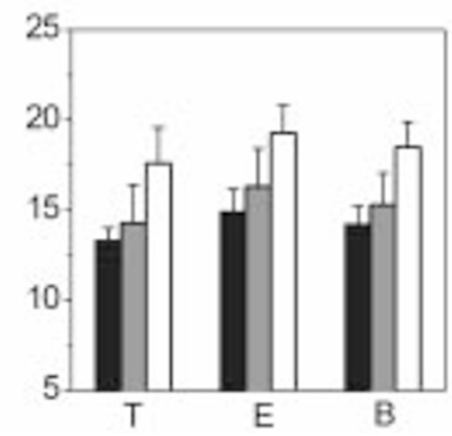

Figure. 5. Effect of Euryale ferox on SOD (A), CAT (B) and GPX (C) activity in V79-4 cells. Each experiment was performed at least 3 times and data are expressed as average enzyme unit per mg protein from control \pm S.D. T, total extracts; $\mathrm{E}$, ethyl acetate fractions; B, butanol fractions. Black, gray and white bars indicate 4, 20 and $100 \mathrm{mg} / \mathrm{ml}$ of samples, respectively.

increased in CAT activity. The CAT activity of control cells (not treated with extracts) was $14.9 \pm 1.9 \mathrm{U} / \mathrm{mg}$ protein. GPX activity was also dose-dependently increased by each of the treatment conditions (Figure 5C). In fact, Euryale ferox extracts activated GPX more strongly than SOD and CAT activities. At a dose of 100 $\mu \mathrm{g} / \mathrm{ml}$, total extracts, ethyl acetate fractions, and butanol fractions activated GPX by 50, 65 and $58 \%$, respectively. The activity of GPX in control cells untreated with extracts was $11.7 \pm 1.3 \mathrm{U} / \mathrm{mg}$ protein.

\section{Discussion}

Reactive oxygen species (ROS) are unwanted metabolic by-products of normal aerobic metabolism under high levels of $\mathrm{O}_{2}$ pressure. High levels of ROS create oxidative stress, which leads to a variety of biochemical and physiological lesions. Such cellular damage often impairs metabolic function and leads to cell death (Finkel and Holbrook, 2000). Cells are protected from ROS-induced damage by a variety of endogeneous ROS scavenging enzymes, chemical compounds and natural products. Recently there has been increasing interest in the therapeutic potential of natural medicinal plants as antioxidants in reducing such free radical-induced tissue injury, suggesting that many plants have antioxidant activities that could be therapeutically useful. Kim et al. (1996) found ginsenoside $R b_{1}$, a major saponin from Panax ginseng, was able to prevent lipid peroxidation. Hepatic lipid peroxide contents were examined in rats treated with extract of Kalopanax pictus stem bark (Choi et al., 2001). For this reason, we have characterized the antioxidant properties of Euryale ferox, a natural medicinal plant which has been previously reported to have immunostimulatory effects (Puri et al., 2000).

Total extracts of Euryale ferox significantly increased DPPH free radical scavenging and inhibited lipid peroxidation in a dose-dependent manner. Total extracts also enhanced viability in V79-4 cells exposed to $\mathrm{H}_{2} \mathrm{O}_{2}$. The protective effect on $\mathrm{H}_{2} \mathrm{O}_{2}$-induced apoptosis was observed. Cells exposed to $\mathrm{H}_{2} \mathrm{O}_{2}$ exhibit distinct morphological features of programmed cell death, such as nuclear fragmentation. Cells which was pretreated with Euryale ferox extracts did not show nuclear fragmentation. Their microscopic morphology was very similar to that of the control cells. These data suggested that Euryale ferox protected cells from $\mathrm{H}_{2} \mathrm{O}_{2}$-induced apoptosis. Detailed mechanistic study of apoptosis inhibitory effect of Euryale ferox is now in progress.

Euryale ferox extracts were subjected to a series of organic separation steps and the various fractions were assayed for DPPH radical scavenging activity. These experiments suggested that specific constituents in the ethyl acetate and butanol fractions contribute to the antioxidant activity of Euryale ferox. This hypothesis is further supported by the finding that the ethyl acetate and butanol fractions also strongly inhibit lipid peroxidation. Lipids are considered to be extremely susceptible to the oxidation by ROS. In particular, polyunsaturated fatty acids located in cellular membranes and in blood are highly prone to attack, leading to the generation of lipid peroxides (Halliwell and Gutteridge, 1998). Lipid peroxidation is an autocatalytic process which is a common cause of cell death. Therefore, inhibition of lipid peroxidation has been used as an important index of antioxidant activity. In the case of cells treated with the ethyl acetate fractions, cell viability was even higher than in control cells. These data suggest that components within the ethyl acetate fractions may have inherent properties that enhance cell viability, in addition to an anti-oxidative protective effect.

We also observed that treating cells with total extracts, ethyl acetate fractions, and butanol fractions of Euryale ferox increased the activity of all antioxidant enzymes examined, including SOD, CAT and GPX. These enzymes are modulated in various diseases 
caused by free radical attack (Halliwell and Gutteridge, 1998). Thus, maintaining the balance between the rate of generation of radicals and scavenging of radicals is an essential part of biological homeostasis. It is of particular interest to note that SOD catalyzes the breakdown of $\mathrm{O}_{2} \cdot$ to $\mathrm{O}_{2}$ and $\mathrm{H}_{2} \mathrm{O}_{2}$, prevents formation of $\mathrm{OH}^{-}$and has thereby been implicated as an essential defense against the potential toxicity of oxygen. The ROS scavenging activity of SOD is effective only when it is followed by the actions of CAT and GPX, because the dismutase activity of SOD generates $\mathrm{H}_{2} \mathrm{O}_{2}$, which needs to be further scavenged by CAT and GPX. Extracts from Euryale ferox activated GPX to a greater extent than the other enzymes examined in this study. This appears that can be effectively scavenged $\mathrm{H}_{2} \mathrm{O}_{2}$ formed by SOD actions. Taken together, these results also suggest that the antioxidant activity of Euryale ferox may be due to degradation of $\mathrm{H}_{2} \mathrm{O}_{2}$ and other peroxides.

In conclusion, extracts from Euryale ferox have high levels of DPPH radical scavenging activity, inhibit lipid peroxidation, promote cell viability, protect $\mathrm{H}_{2} \mathrm{O}_{2}$-induced apoptosis and enhance the effects of various antioxidant enzymes. These findings strongly suggest that Euryale ferox has antioxidant activity. Among various fractionated samples of Euryale ferox, the ethyl acetate fractions and butanol fractions exhibited relatively high levels of antioxidant activity. Constituents within these fractions may play an important role as natural antioxidants. Further studies are aimed at isolating and identifying these active constituents and elucidating the mechanisms by which Euryale ferox regulates cellular metabolism.

\section{Acknowledgements}

This study was Mid-and-Long-term Nuclear R\&D Program supported by the fund from Ministry of Science and Technology, Korea. S. E. Lee is a post-doctoral researcher and $\mathrm{E}$. M. Ju is a graduate fellow of Brain Korea 21 program supported by Ministry of Education, Korea.

\section{References}

Banskota AH, Tezuka Y, Adnyana IK, Message D, Kadota S. Cytotoxic, hepatoprotective and free radical scavenging effects of propolis from Brazil, Peru, the Netherlands and China. J Ethnopharmacol 2000;72;239-46

Beauchamp C, Fridovich I. Assays of superoxide dismutase. Anal Biochem 1971;44;276-87

Blosi MS. Antioxidant determinations by the use of a stable free radical. Nature 1958;181;1199-200

Borek C. Free radical processes in multistage carcinogenesis.
Free Radic Res Commu 1991;12;745-50

Bradford MM. A rapid and sensitive method for the quantitation of microgram quantities of protein utilizing the principle of protein-dye binding. Anal Biochem 1976;72;248-54

Brown JE, Rice-Evans CA. Luteolin-rich artichoke extract protects low density lipoprotein from oxidation in vitro. Free Radic Res 1998;29;247-55

Cao G, Sofic E, Prior RL. Antioxidant and prooxidant behaviour of flavonoids: Structure-activity relationships. Free Radic Biol Med 1996;22;749-60

Carrillo MC, Kanai S, Nokubo M, Kitani K. Deprenyl induces activities of both superoxide dismutase and catalase but not glutathione peroxidase in the striatum of young male rats. Life Sci 1991;48;517-21

Choi JW, Han YN, Lee KT, Park KY, Kwak TS, Kwon SH, Park HJ. Anti-lipid peroxidative principles from stem bark of Kalopanax pictus Nakai. Exp Mol Med 2001;24;536-40

Deiana M, Aruoma OI, Bianchi M, Halliwell B, Aeschbach R, Corongiu FP. Inhibition of peroxinitride-dependent DNA base modification and tyrosine nitration by the extra virgin olive oilderived antioxidant hydroxytyrosol. Free Radic Biol Med 1999; 26;762-69

Finkel T, Holbrook NJ. Oxidants, oxidative stress and the biology of ageing. Nature 2000;408;239-47

Frlich I, Riederer P. Free radical mechanisms in dementia of Alzheimer type and the potential for antioxidative treatment. Drug Res 1995;45;443-49

Gohil K, Moy RK, Farzin S, Maguire JJ, Packer L. mRNA expression profile of a human cancer cell line in response to Ginkgo biloba extract: induction of antioxidant response and the Golgi system. Free Radic Res 2000;33;831-49

Halliwell B, Gutteridge JMC. Free Radicals in Biology and Medicine. 3rd Ed., 1998, Oxford University

Hansen MB, Nielsen SE, Berg K. Re-examination and further development of a precise and rapid dye method for measuring cell growth/cell kill. J Immunol Methods 1989;119;203-10

Keum YS, Park KK, Lee JM, Chun YS, Surh YJ. Antioxidant and anti-tumor promoting activities of the methanol extract of heat-processed ginseng. Cancer Lett 2000;150;41-48

Kim JS, Oh JH, Lee DW, Park HJ, Park DK. Effect of ginsenoside $R b_{1}$ on lipid peroxidation and neurotoxicity induced by MPTP in liver and brain of mouse. Exp Mol Med 1996;28:199-205

Kitts DD, Yuan YV, Wijewickreme AN, Hu C. Antioxidant properties of a North American gingseng extract. Mol Cell Biochem 2000;203:1-10

Ohkawa H, Ohishi N, Yagi K. Assay for lipid peroxide in animal tissues by thiobarbituric acid reaction. Anal Biochem 1979;95:351-58

Paglia DE, Valentine WN. Studies on the quantitative and qualitative characterization of erythrocyte glutathione peroxidase. J Lab Clin Med 1967;70:158-64

Puri A, Sahai R, Kiran L, Singh RP, Saxena KC. 
Immunostimulant activity of dry fruits and plant materials used in Indian traditional medical system for mothers after child birth and invalids. J Ethnopharmacol 2000;71:89-92

Roedig-Penman A, Gordon MH. Antioxidant properties of catechins and green tea extracts in model food emulsions. J Agric Food Chem 1997;45:4267-70

Wang H, Cao G, Prior RL. Total oxidant capacity of fruits. J Agric Food Chem 1996;44:701-5
Witztum JL. The role of oxidized lox density lipoproteins in atherogenesis. Br. Heart J 1993;69:12-14

Zhao H, Zhao S. New Cerebrosides from Euryale Ferox. J Nat products 1994;57:138-41

Zhao H, Zhao S, Sun C, Guillaume D. Glucosylsterols in extracts of Euryale ferox identified by high resolution NMR and mass spectrometry. J Lipid Res 1989;30:1633-63 